DOI: 10.20472/BMC.2019.010.004

\author{
CELANI JOHN NYIDE \\ Durban University of Technology, South Africa
}

\title{
A QUALITATIVE INVESTIGATION OF THE ENVIRONMENTAL MANAGEMENT ACCOUNTING PRACTICES FOR THE OPTIMISATION OF ENVIRONMENTAL COSTS IN THE SOUTH AFRICAN HOTEL SECTOR
}

\begin{abstract}
:
The successful management of environmental impacts and environmental costs depends on the implementation of the appropriate Environmental Management Accounting practices (EMAPs). EMAPs provides a pragmatic response to the widely reported criticisms of conventional management accounting practices. This paper reports on the EMAPs evident from the hotel sector in South African, used in order to optimise of environmental costs. Purposive sampling was used to select the hotel group that met the discriminatory criterion. Considering that this study was exploratory in nature, in-depth interviews were conducted with 10 respondents. The study found that the implementation EMAPs is limited in the South African hotel sector. This is due to the fact that the implementation of these practices is voluntary at this stage and there is no awareness by the hotels of the existing framework that they can use. Moreover, there is negligible pressure from the government for the hotels to see a need to reduce their environmental costs. Environmental Cost Accounting and Material Flow Cost Accounting are prominently used by the investigated hotels for the optimisation of environmental costs. The development and implementation of new technologies that complement EMAPs were found to be a challenge because of the shortage of skilled personnel and massive investments.
\end{abstract}

\section{Keywords:}

Environmental Management Accounting Practices, Environmental Costs, Hotel Sector, Optimisation, South Africa

JEL Classification: Q51, Q56, G30 


\section{INTRODUCTION}

The hotel sector contributes significantly to the South African economy. The sector has seen tremendous growth post-apartheid South Africa (Hoogendoorn, Grant and Fitchett, 2015; and Rogerson, 2013). The 2013/2014 annual report by the National Department of Tourism (NDT, 2015) shows that the country's travel and tourism industry, of which the hotel sector is part, contributed over $\$ 10$ billion to the economy of the country. Of critical concern though, is that the services offered by the hotel and the operational mechanisms applied, if not efficiently managed, can lead to substantial quantities of energy and water used by this industry being wasted. Hotels are "known for their consumption of substantial quantities of energy, water, and non-durable products" (Smith \& Leonard, 2018), which causes adverse impacts on the environment (Nyide, 2017). As such, Chan and Hawkins (2012); Mbasera, du Plessis, Saayman and Kruger (2018) assert that the hotel sector is challenged with a paramount assignment to decisively address environmental issues.

South African hotels are gradually starting to implement initiatives that are geared towards improving their environmental performance (Smith \& Leonard, 2018; Nyide, 2017). These initiatives mainly focus on addressing energy consumption, water use efficiency and waste management (Nyide, 2016). Van der Merwe and Wocke (2007); Smith and Leonard (2018) mention that out that "very few hotels participate in these initiatives because they are voluntary". The environmental initiatives which are implemented by some hotels are not regulated by government (Rogerson and Sims, 2012; Nyide, 2017). Janković and Krivačić (2014) argue that there is resistance in the hotel sector to undertake formal environmental management programmes. When implemented efficiently, these programmes, which include Environmental Management Accounting Practices (EMAPs), have been found to be "able to detect, measure, record and analyse environmental costs in order to optimise them" (Fukey and Issac, 2014). Understanding environmental costs is potentially a motivating factor for organisations to implement EMAPs to facilitate the decision-making processes for organisations (Parker and Chung, 2018). This paper will describe EMAPs used by the South African hotel sector to optimise environmental costs.

\section{ENVIRONMENTAL CHALLENGES IN THE SOUTH AFRICAN HOTEL SECTOR}

Even though the South African government has noted the importance of responsible tourism and environmental sustainability, it is argued that the existing policies do not maintain clear strategies for managing the impact on the environment contributed by the hotels (Leonard and Dlamini, 2014). To expand on this argument, Smith and Leonard (2018) mention that "vague policies and the lack of a trained workforce within the Department of Environmental Affairs and Tourism add to the challenges". As a result, the South African government is challenged by the international 
organisations to "enforce its own legal framework" (Wyngaard and de Lange, 2013). The major environmental challenges facing the hotel sector as evident in the literature relate to water, energy and waste management focusing on the three major environmental challenges that form part of the research objectives.

\section{Water challenges in South Africa}

South Africa is considered a water-stressed country that is challenged with limited water resources (Mhlongo, Mativenga \& Marnewick, 2018). According to Doneva, van Sarka, Bloka, and Dintchev, (2012), the average annual rainfall in South Africa is less than the world's average. The availability of water remains uncertain because water supply is reliant on weather conditions. This is supported by Kasim, Gursoy, Okumus, and Wong (2014), who point out that water supply disruptions are caused by weather conditions. During dry seasons, several countries obtain water from "deep ground sources and this causes many non-renewable resources to deplete and this may cause future humanitarian crises if no remedial action is taken" (Kasim et al., 2014). As alluded to above, the South African hotel sector has been experiencing significant growth over the years. Inevitably, this growth is coupled with water consumption practices that are unsustainable and this compromises the ecosystems. Hotels consume high volumes of water as compared to households due to the nature of these entities. Gössling, Peeters, Hall, Ceron, Dubois, Lehmann, and Scott (2012) add that hotels consume large quantities of water to keep gardens attractive, for daily cleaning of rooms coupled with laundry services, for kitchen services and swimming pools. Literature reveals that South Africa is facing physical water scarcity with demand estimated to outstrip supply at the current consumption rates (Gulati, Jacobs, Jooste, Naidoo and Fakir, 2013; Mhlongo et al., 2018). Some parts of the country have witnessed water shedding (restrictions) to address the scourge of water shortages. The available water and electricity resources in South Africa cannot sustain the ever increasing consumption demands from the hotel sector (Hoogendoorn et al., 2015).

\section{Energy crises in South Africa}

South Africa is an energy-intensive economy (Winkler, 2006; Ateba \& Prinsloo, 2019). The coal and oil are the main means of meeting South Africa's energy needs and the coal alone accounts for about $72 \%$ of energy (Lin and Wesseh, 2014). The country has achieved a rate of over $75 \%$ of electrification nationwide and also exports electricity to neighbouring countries (Lin and Wesseh, 2014). The demand for electricity has hastily grown surpassing the supply in the past few decades and this has led to rolling blackouts. Even though rolling blackouts or load shedding, as it is referred to, were suspended in May 2008, it has been re-introduced since November 2014. Erdogan and Baris (2007); Oluseyi, Babatude and Babatunde, (2016) reveal that, for the hotel industry, "energy use is a cost 
factor and generally requires the consumption of non-renewable resources" and hotels, by virtue of their operations, are high energy consumers. In spite of the prevailing environmental impacts, most hoteliers still find it difficult to implement EMAPs because they believe that it will impact adversely on the customer experiences with their service offering (Janković and Krivačić, 2014).

\section{Waste management challenges}

Wyngaard and de Lange (2013) report that "approximately 1499 litres of water is used daily in a single luxury hotel room and hotels produce food waste of up to $46 \%$ of a hotel's total waste". Pirani and Arafat (2014) estimate that over 1 kilograms of waste in generated by a single hotel guest on a daily basis. This is a serious concern for the environment and for the hotel sector. Inevitably, this has cost implications for hotels (disposal costs) and the environment (lost materials) (Fakoya and van der Poll, 2013). Janković and Krivačić (2014) maintain that hotels carry a huge environmental cost burden as a result of solid waste and waste water management operations. The main environmental waste-related issues emanate from "food processing, high water consumption, the discharge of high strength effluent and the consumption of energy" (Massoud, Fayad, El-Fadel and Kamle, 2010).

\section{EMAPs USED BY THE HOTEL SECTOR}

Chan and Hawkins (2012) notes that organisations have implemented a couple of unsanctioned EMAPs, mainly to reduce energy and water consumption and save costs. Oreja-Rodríguez and Armas-Cruz (2012); Nyide (2017) point out that the majority of EMAPs used by the hotel sector are less complicated are of "low cost". They are designed to aid hotels with their normal daily operations in order to track and reduce energy and water consumption and costs and also to facilitate waste management. EMPAs, whether formal or informal, always cover the main environmental domains against which the firms' environmental performance is assessed, that it, water, energy and waste management.

In a study conducted by Gunarathne and Lee (2015) in Sri Lanka, it is found that EMAPs are integrated with the hotel's management system with the aim of improving the hotel's environmental performance. The aforementioned authors found that the majority of hotels use environmental impact assessment and life cycle design as environmental management tools. In line with literature, these tools are at an infancy stage and they focus on water and energy and, later and waste. Buyukipekci (2014), on the other hand, conducted a qualitative study in the Turkish hotel sector and reports that life cycle assessment (environmental assessment impact and life cycle design) and material flow cost accounting (MFCA) were applied by the investigated hotels. The application of EMAPs in the 
Turkish hotel sector is at an elementary stage and there is generally limited awareness of these practices in the sector.

In the Croation hotel sector, Janković and Krivačić (2014) report that there is limited research in this domain for hotels and the authors pointed out that this is an indication that EMAPs are poorly at play within the hotel sector. Similarly, Castellania and Sala (2012) assert that limited research has been undertaken in Italy to specifically evaluate hotels' environmental impacts arising from their operations. However, life cycle assessment was acknowledged as have been used in the hotel sector to assess the hotels' impact on the environment. Unlike countries mentioned above, Priego, Najerab, and Font (2011) point out that Spanish hotels are amongst leaders in environmental performance in Europe. The degree of awareness, knowledge and skills, relating to the EMAPs is fairly high in these hotels (Priego et al. (2011). In Spain, EMAPs are reported to have been used as a tool to improve internal and external reporting objectives. They have been reportedly used to estimate costs and investments and aid investment decisions undertaken by hotels for their environmental management (Priego et al., 2011).

In Africa, the application of EMAPs by hotels is largely hindered by requisite resources, that is, personnel with the knowledge and skills for undertaking environmental management, processes and systems that engender improved environmental performance (Mensah, 2014). Sucheran (2013) add that EMAPs are associated with high costs and complexities. Consequently, the resource insufficient small-scale establishments are unable to make the costly technological investments for environmental management and are thus precluded from meeting the environmental management standards and improved organisational performance (Mensah, 2014; Sucheran, 2013).

\section{RESEARCH METHODOLOGY}

The empirical part of this study was performed in a way of a qualitative case study (with embedded units) research method. The assessment of environmental costs requires the collection of data to do with organisational costs, revenue, and profits, all of which are usually regarded highly confidential (Setthasakko, 2010). It is unlikely that this data can be collected from all the companies in a large sample (Gunarathne and Lee, 2015). This problem necessitated the use of the qualitative approach. As a result of the aforementioned challenges, several studies have applied the same methodology to unravel complex phenomena similar to this study (Chan and Hawkins, 2012; Buyukipekci, 2014; Gunarathne and Lee, 2015; Nyide, 2017). Since the application of EMAPs is at an elementary stage in the South African hotel sector (Rogerson and Sims, 2012; Nyide, 2017), the use of case study as a research methodology to collect data, was therefore, deemed appropriate in order to provide rich descriptions, considerations and clarifications of the events being investigated. 
Purposive sampling as hotels that formed part of the case study had to meet the discriminatory criteria. Hotels had to have an existing environmental management system (EMS). Moreover, the sample consisted of hotel employees who occupy positions in the finance, maintenance, and general management sections. ABC Hotel Management Group (a pseudo name used for confidentiality purposes) formed part of this study along its 3 hotels. A total of 10 managers, including a group engineer who is responsible for the development and implementation of EMS at ABC Hotel Management Group, participated in this study. In-depth semi-structured interviews were conducted to collect data. These were conducted between October and November 2018. Cross-case syntheses were used to analyse data after thematic coding was performed to categorise findings from hotels under investigation.

To enhance reliability of data collected, participants were asked the same interview questions. Participants were also involved in reviewing the transcripts for accuracy (Lapan, Quaetaroli and Riemer, 2012). Moreover, data was also collected from company documents such as financial reports, policy documents and also the hotels' websites. These included the hotels' Group Energy Profile Analysis programme (GEPA), Building Management System (BMS), financial statements, policies and the group websites together with their individual hotel websites.

\section{RESEARCH FINDINGS}

Given that the approach used was a single case study with embedded units, a cross-case synthesis was used to analyse data using complementary word tables. Research findings are discussed under the research theme that emerged in this study. This theme was developed to cater for the objective of this paper on the interview questions. These questions were designed to identify the EMAPs used by the hotel sector for the optimisation of environmental costs

\section{Table 1 Procedure to assess environmental performance}

Question 1 Does the hotel have a procedure to assess the hotel's environmental performance? If yes, please describe.

\begin{tabular}{|c|c|c|c|}
\hline Hotel A & Hotel B & Hotel C & Group Engineer \\
\hline $\begin{array}{l}\text { Yes. Environmental } \\
\text { performance is } \\
\text { assessed and reported } \\
\text { monthly using BMS. } \\
\text { It is audited by Green } \\
\text { Leaf. }\end{array}$ & $\begin{array}{l}\text { Yes. In line with } \\
\text { Green Leaf Eco } \\
\text { Standard. }\end{array}$ & $\begin{array}{l}\text { Yes. It is reported } \\
\text { monthly, in line with } \\
\text { Green Leaf Eco } \\
\text { Standard. }\end{array}$ & $\begin{array}{l}\text { Yes. It is assessed and } \\
\text { reported using GEPA. }\end{array}$ \\
\hline
\end{tabular}


Table 1 shows that the environmental performance is assessed across the board using Green Leaf Eco Standard (an EMS). Hotel A is assisted by its BMS system to assess its environmental performance. All these hotels report their environmental performances to the group engineer who then collates all the information using GEPA. Therefore, analysing the procedures followed by ABC Hotel Management Group to assess their environmental performance could assist in determining the extent at which the EMAPs are used by this organisation to optimise environmental costs.

\section{Table 2 Environmental reporting and major environmental costs}

\begin{tabular}{|c|c|c|c|c|}
\hline Question 2 & \multicolumn{4}{|c|}{$\begin{array}{l}\text { Does the hotel have any form of environmental reporting? If yes, what is reported? Is it } \\
\text { including the major environmental costs? At what level are the major environmental } \\
\text { costs reported (if any)? }\end{array}$} \\
\hline \multicolumn{2}{|c|}{ Hotel A } & Hotel B & Hotel C & Group Engineer \\
\hline \multicolumn{2}{|c|}{$\begin{array}{l}\text { Yes. } \\
\text { Energy and water } \\
\text { consumption are } \\
\text { reported monthly } \\
\text { using the internal } \\
\text { system (BMS). It is } \\
\text { reported hotel wide. }\end{array}$} & $\begin{array}{l}\text { Yes. } \\
\text { Energy, water and } \\
\text { waste are reported } \\
\text { subject to Green Leaf } \\
\text { Eco Standard. These } \\
\text { are reported monthly } \\
\text { across all divisions } \\
\text { with the hotel. }\end{array}$ & $\begin{array}{l}\text { Yes. } \\
\text { Energy, waste and } \\
\text { water. } \\
\text { Reported internally } \\
\text { across the board. }\end{array}$ & $\begin{array}{l}\text { Yes. } \\
\text { Reported monthly to the } \\
\text { regional manager. It is } \\
\text { included in the General } \\
\text { managers' pack. } \\
\text { Water, energy and occupancy } \\
\text { (which includes } \\
\text { conferencing, bed nights sold } \\
\text { and room nights sold). } \\
\text { The reporting is done across } \\
\text { all departments. }\end{array}$ \\
\hline
\end{tabular}

In Table 2, the hotel management was positive towards the question. However, there appears to be an inconsistency in the way environmental reporting is done. Having said that, energy, water and waste are the major costs reported by hotels B and C, whilst A focuses on energy and water consumption and these were also mentioned by the group engineers who also added occupancy-related information. The literature reveals that the formation and practice of environmental management and environmental reporting is commonly voluntary and not regulated by law and some information is often missing or omitted in the reports (Janković and Krivačić, 2014). This could be the contributing factor to the lack of standardised information reported by the hotels under study. 


\section{Table 3 Tracing of environmental costs}

Question 3 Does the hotel trace any of the major environmental costs (either physical or monetary)? If yes, what are they and how are they categorised?

\begin{tabular}{|c|c|c|c|}
\hline Hotel A & Hotel B & Hotel C & Group Engineer \\
\hline $\begin{array}{l}\text { Both physical and } \\
\text { monetary. } \\
\text { These are recorded } \\
\text { separately. } \\
\text { Water and lights. }\end{array}$ & $\begin{array}{l}\text { 'Consumption more } \\
\text { than monetary' } \\
\text { Recorded separately. } \\
\text { Energy, water and } \\
\text { waste. }\end{array}$ & $\begin{array}{l}\text { Physical information } \\
\text { Recorded separately. } \\
\text { Water, energy and } \\
\text { waste. }\end{array}$ & $\begin{array}{l}\text { Yes, GEPA is used to trace } \\
\text { the major environmental } \\
\text { costs. Both monetary and } \\
\text { physical information is } \\
\text { recorded. Water, energy } \\
\text { and occupancy information. }\end{array}$ \\
\hline
\end{tabular}

According to Table 3, respondents were in agreement to the question and to recording the major environmental costs separately. However, there was no consensus on the way the major environmental costs are traced. The group engineer reported that environmental costs are traced using both financial and physical information. This is similar to what hotel A is doing. On the contrary, hotels $\mathrm{B}$ and $\mathrm{C}$ trace the major environmental costs using physical information more than monetary information. Water and energy are the major costs widely traced by the group even though hotels B and $\mathrm{C}$ also trace waste-related costs (physical). As indicated in the above discussion, environmental reporting can be considered as the necessity to demonstrate the hotels' environmental responsibility. It is noted, however, that the disclosed environmental information is not fully comparable amongst all hotels within the group. This makes it difficult to measure data used.

\section{Table 4 The basis for the allocation of major environmental costs}

\begin{tabular}{|c|c|c|c|c|}
\hline Question 4 & \multicolumn{4}{|c|}{$\begin{array}{l}\text { On what basis are the major environmental costs traced and recorded? Or are they } \\
\text { considered more generally (such as hotel wide)? What is the purpose of tracing and } \\
\text { recording? }\end{array}$} \\
\hline \multicolumn{2}{|c|}{ Hotel A } & Hotel B & Hotel C & Group Engineer \\
\hline \multicolumn{2}{|c|}{$\begin{array}{l}\text { 'Show savings year } \\
\text { on year' and for } \\
\text { benchmarking } \\
\text { purposes. }\end{array}$} & $\begin{array}{l}\text { Occupancy (room } \\
\text { night/bed night). } \\
\text { Monitoring and } \\
\text { control. }\end{array}$ & $\begin{array}{l}\text { Bed night factor } \\
\text { Monitoring and } \\
\text { reporting. }\end{array}$ & $\begin{array}{l}\text { Traced live (minute by } \\
\text { minute) } \\
\text { Cost-saving, performance } \\
\text { monitoring and } \\
\text { benchmarking. }\end{array}$ \\
\hline
\end{tabular}


Table 4 shows that informants were all in agreement with the questions asked by reporting that occupancy (bed night or room night) is the basis for tracing the major environmental costs. The group engineer's emphasis of tracing and recording the environmental costs is cost saving, performance and monitoring. These assertions are partly supported by the management of the embedded units. According to Mensah and Blankson (2013), there is a strong correlation between energy and water consumption and occupancy rate. Farouk et al., (2012) maintain that environmental costs can be traced in an effective and systematic manner if an organisation has an environment management system in place.

\section{Table 5 Internal reporting of environmental performance}

Question 5 Does the hotel issue any internal report on environmental performance? If yes, at what level is the environmental performance assessed?

\begin{tabular}{|l|l|l|l|}
\hline \multicolumn{1}{|c|}{ Hotel A } & \multicolumn{1}{|c|}{ Hotel B } & \multicolumn{1}{c|}{ Hotel C } & \multicolumn{1}{c|}{ Group Engineer } \\
\hline $\begin{array}{l}\text { Yes. } \\
\text { Departmentally. }\end{array}$ & $\begin{array}{l}\text { No. } \\
\text { Done by Green Leaf. }\end{array}$ & $\begin{array}{l}\text { Yes. } \\
\text { Reported hotel-wide. }\end{array}$ & $\begin{array}{l}\text { Yes. } \\
\text { Between properties to head } \\
\text { office. }\end{array}$ \\
\hline
\end{tabular}

Comments in Table 5 were generally positive towards the questions. However, there was some consideration that hotel B was not very sure about it. It is for these reasons that Mensah (2014) argues it is pivotal for hotels to be endowed with skills and knowledge required to operate environmental management programmes and systems. This ensures that optimised environmental performance is recorded and reported.

\section{Summary of key finings}

The study found that the investigated Hotel Group has started to engage on EMAPs and developed technologies that are concentrated on improving the Group's environmental and economic performance, such as improving water consumption efficiencies, energy consumption efficiencies and efficient waste management. To demonstrate its commitment, the Group has commenced with the certification of its hotels in terms of the Green Leaf Eco Standard and the Group is also involved with the Heritage Environmental Programme which is intended to rate the Group's environmental and sustainability practices in line with the globally recognised and professional standards. The study found that Environmental Cost Accounting (ECA) and MFCA are the main techniques utilised by the investigated hotels within the Group. The hotels' understudy focus on the allocation of environmental costs to activities with the aim of determining costs created and costs avoided by the hotels' operations and this is a description of ECA. Moreover, these hotels have developed technologies such 
as BMS and GEPA, not only to allocate environmental costs to activities but also to trace and record flows of energy and water.

\section{LIMITATIONS}

The focus of this study was hotels situated in the province of KwaZulu-Natal. Moreover, a single case study with embedded units was used as a research approach. This is coupled with a limited sample size. Therefore, generalisation should be exercised with caution.

\section{IMPLICATIONS}

It can be maintained that, for better management of the environmental costs, the hotel sector needs to have a clear understanding of the relevant EMAPs, applications and strategies that can be utilised to assist the sector in optimising environmental costs. Theories about the EMAP used by the hotel sector have not been widely published in the literature as stated in this study. The integration of environmental management initiatives within the hotel sector, such as the certification programmes, with the EMA tools, constitute the theoretical contribution of this study. The success of the management of the major environmental costs in the hotel sector depends on the adoption of an innovative approach as compared to the conventional management accounting systems.

\section{RECOMMENDATIONS FOR FUTURE RESEARCH}

It is recommended that a longitudinal case study be conducted to identify and evaluate EMAPs used by the hotel sector. This would provide a more an extensive and a comprehensive examination of the application of EMAPs the hotel sector. Moreover, a multiple case study approach can be pursued. Future research is also recommended in a form of quantitative research to address the shortcomings embedded in the qualitative research method.

\section{REFERENCES}

Ateba, B.B. and Prinsloo, J.J. 2019. Strategic management for electricity supply sustainability in South Africa. Utilities Policy, 56: 92 - 103.

Buyukipekci, S. 2014. Green Accounting Applications in Accommodation Services as a Part of Sustainable Tourism. Journal of Advanced Management Science, 2 (3): 192 - 196. 
Castellania, V. and Sala, S. 2012. Ecological Footprint and Life Cycle Assessment in the sustainability assessment of tourism activities. Ecological Indicators, 16: 135 - 147.

Chan, E.W.S. and Hawkins, R. 2012. Application of EMSs in a hotel context: a case study. International Journal of Hospitality Management, 31: 405 - 418.

Doneva, G., van Sarka, W.G.J.H.M., Bloka, K. and Dintchev, O. 2012. Solar water heating potential in South Africa in dynamic energy market conditions. Renewable and Sustainable Energy Reviews, 16: $3002-3013$.

Erdogan, N. and Baris, E. 2007. Environmental protection programs and conservation practices of hotels in Ankara, Turkey. Tourism Management, 28: 604-614.

Gössling, S. Peeters, P. Hall, C.M., Ceron, J.P., Dubois, G., Lehmann, G. and Scott, D. 2012. Tourism and water use: Supply, demand, and security. An international review. Tourism management, 33: 1 15.

Gulati, M., Jacobs, I., Jooste, A., Naidoo, D. and Fakir, S. 2013. The water-energy-food security nexus: Challenges and opportunities in South Africa. Aquatic Procedia, 1: 150 - 164.

Gunarathne, N. and Lee, K.H. 2015. Environmental Management Accounting (EMA) for environmental management and organizational change: An eco-control approach. Journal of Accounting \& Organizational Change, 1 (3): 362 - 383.

Hoogendoorn, G., Grant, B. and Fitchett, J. 2015. Towards green guest houses in South Africa: the case of Gauteng and KwaZulu-Natal. South African Geographical Journal, 97 (2): 123 - 138.

Janković, S. and Krivačić, D. 2014. Environmental accounting as perspective for hotel sustainability: Literature review. Tourism and Hospitality Management, 20 (1): 103 - 120.

Kasim, A., Gursoy, D., Okumus, F. and Wong, A. 2014. The importance of water management in hotels: a framework for sustainability through innovation. Journal of Sustainable Tourism, 22 (7): $1090-1107$.

Leonard, L. and Dlamini, T. 2014. Greening within the Johannesburg tourism and hospitality sectors. African Journal of Hospitality, Tourism and Leisure, 4 (2): 1 - 8. 
Lin, B. and Wesseh, P.K. 2014. Energy consumption and economic growth in South Africa reexamined: A nonparametric testing approach. Renewable and Sustainable Energy Reviews, 40: 840 850.

Lapan, S.D., Quaetaroli, M.T. and Riemer, F.J. (eds). 2012. Qualitative Research: An introduction to methods and designs. San Francisco: John Wiley and Sons.

Massoud, M.A., Fayad, R., El-Fadel, M., and Kamle, R. 2010. Drivers, barriers and incentives to implementing environmental management systems in the food industry: A case of Lebanon. Journal of Cleaner Production, 18 (2010): 200 - 209.

Mbasera, M., du Plessis, E., Saayman, M., Kruger, M. 2018. Determining the impact of green management policies on hotel performance: A manager's perspective. African Journal of Hospitality, Tourism and Leisure, 7 (3): 1 - 13.

Mensah, I. 2014. Stakeholder pressure and hotel environmental performance in Accra, Ghana. Management of Environmental Quality: An International Journal, 25 (2): 227 - 243.

Mensah, I. and Blankson, E. 2013. Determinants of hotels' environmental performance: Evidence from the hotel industry in Accra, Ghana. Journal of Sustainable Tourism, 21 (8): 1212 - 1231.

Mhlongo, S., Mativenga, P.T., Marnewick, A. 2018. Water quality in a mining and water-stressed region. Journal of Cleaner Production 171: 446 - 456.

National Department of Tourism (NDT). 2015. Annual Report 2013/2014. Vote 35. [Online]. Available from:

http://www.tourism.gov.za/AboutNDT/Publications/NDT\%20Annual\%20Report\%202013_14.pdf [Accessed on: 29/06/2015].

Nyide, C.J. 2017. The role of environmental management accounting and voluntary self-regulation initiatives in improving resource efficiency in South Africa. Business and Economic Horizons, 13(1): $30-41$.

Oluseyi, P.O., Babatunde, O.M. and Babatunde, O.A. 2016. Assessment of energy consumption and carbon footprint from the hotel sector within Lagos, Nigeria. Energy and Buildings, 118: 106-113. 
Oreja-Rodríguez, J.R. and Armas-Cruz, Y. 2012. Environmental performance in the hotel sector: the case of the Western Canary Islands. Journal of Cleaner Production, 29-30: 64 - 72.

Parker, L.D. and Chung, L.H. 2018. Structuring social and environmental management control and accountability: Behind the hotel doors. Accounting, Auditing \& Accountability Journal, 31 (3): 993 1023.

Pavlatos, O. and Paggios, I. 2009. A survey of factors influencing the cost system design in hotels. International Journal of Hospitality Management, 28: 263 - 271.

Priego, M.J.B., Najerab, J.J. and Font, X. 2011. Environmental management decision-making in certified hotels. Journal of Sustainable Tourism, 19 (3): $361-381$.

Rogerson, J.M. 2013. Reconfiguring South Africa's hotel industry 1990 - 2010: structure, segmentation and spatial transformation. Applied Geography, 36: 59-68.

Rogerson, J.M. and Sims, S.R. 2012. The Greening of Urban Hotels in South Africa: Evidence from Gauteng. Urban Forum, 23: $391-407$.

Setthasakko, W. 2010. Environmental Management Accounting: An exploratory study of pulp and paper companies in Thailand. Euromed Journal of Business, 5 (3): 315 - 331.

Smith, C. and Leonard, L. 2018. Examining governance and collaboration for enforcement of hotel greening in Gauteng, South Africa: Towards a network governance structure. e-Review of Tourism Research, 15 (6): 480 - 502.

Sucheran, R. 2013. Environmental management in the hotel and lodge sector in KwaZulu-Natal, South Africa. PhD. dissertation, University of KwaZulu-Natal.

Winkler, H. (ed). 2006. Energy policies for sustainable development in South Africa: options for the future. Energy Research Centre, University of Cape Town.

Wyngaard, A.T. and de Lange, R. 2013. The effectiveness of implementing eco initiatives to recycle water and food waste in selected Cape Town hotels. International Journal of Hospitality Management, 34: 309 - 316. 